ISSN 1392-3196 / e-ISSN 2335-8947

Zemdirbyste-Agriculture, vol. 101, No. 1 (2014), p. 79-84

DOI 10.13080/z-a.2014.101.011

\title{
Amino acid composition of kolomikta actinidia (Actinidia kolomikta (Maxim. \& Rupr.) Maxim) fruits of Lithuanian origin
}

\author{
Aurelija PAULAUSKIENĖ, Živilè TARASEVIČIENĖ, Audronė ŽEBRAUSKIENĖ \\ Aleksandras Stulginskis University \\ Studentų 11, Akademija, Kaunas distr., Lithuania \\ E-mail: aurelija.paulauskiene@asu.lt
}

\begin{abstract}
Fruits of actinidia (Actinidia Lindl.) genotypes are known as a source of vitamins $\mathrm{C}$ and $\mathrm{E}$, minerals, dietary fibre, various organic acids, carotenoids, flavonoids, and other useful compounds, but almost no data are available about proteins and amino acids content. The objective of the study was to determine the amounts of crude protein and amino acids in the fruits of kolomikta actinidia (Actinidia kolomikta (Maxim. \& Rupr.) Maxim.) cultivars. Four Lithuanian cultivars 'Laiba', 'Lankè', 'Landè' and 'Paukštès Šakarva' were investigated. The cultivars were developed at Aleksandras Stulginskis University's research orchard and have been under investigation there for 25 years. The amount of crude protein was determined by the Kjeldahl method. Amino acids were separated by ionexchange chromatography and detected photometrically. The crude protein content of the investigated kolomikta actinidia fruits ranged between $0.96-1.32 \%$. There were no significant differences in the protein content among the cultivars tested. The protein content of kolomikta actinidia fruits is similar to that of another species of actinidiakiwifruits (Actinidia chinensis Planch. (A.Chev) C.F.Liang \& A.R.Ferguson). In kolomikta actinidia fruit, glutamic acid was the predominant amino acid with values ranging from 7.60 to $9.51 \mathrm{~g} \mathrm{~kg}^{-1}$. The highest amount of essential amino acids was in 'Laiba' fruits $\left(17.71 \mathrm{~g} \mathrm{~kg}^{-1}\right)$, while that of nonessential amino acids in 'Lanke' fruits $(33.24 \mathrm{~g}$ $\left.\mathrm{kg}^{-1}\right)$. The recommended ratio of total essential amino acids to the total amino acids, protein efficiency ratio, amount of total nonessential, sulphur, aromatic, neutral, acidic, basic, branched chain amino acids, leucine/isoleucine ratio and their percentage levels in the fruits of all cultivars were calculated. The study showed that amino acids amounts and percentage levels in kolomikta actinidia fruits tested are similar to those in kiwifruits.
\end{abstract}

Key words: Actinidia, biological value of proteins, essential amino acids, nonessential amino acids, protein efficiency ratio.

\section{Introduction}

A high nutritional value of fruits led to a significant increase in their consumption. Recently, many researchers have been recommending the use of fruits, including kiwifruits (Actinidia chinensis), with a high antioxidant activity (Jung et al., 2005; Scalzo et al., 2005). Of almost 50 species of Actinidia genus only kolomikta actinidia (Actinidia kolomikta) is characterized as resistant and bower actinidia (Actinidia arguta (Siebold \& Zucc.) Planch. ex Miq.) as tolerant of Lithuanian climatic conditions.

Kolomikta actinidia is a promising plant in Lithuania, the fruits of which accumulate a complex of biologically active substances (Pranckietis et al., 1999; Chesoniene et al., 2004; Paulauskienè et al., 2009; Pranckietis et al., 2009). Average fruit mass of kolomikta actinidia grown in Lithuania ranges from 2.1 to $4.5 \mathrm{~g}$ (Pranckietis et al., 1999). The fruits are very aromatic with a sweet, intense flavour that has been compared to banana, pineapple, strawberry, pear, blackcurrant, melon and tropical flavours (Matich et al., 2003). The fruits have thin cuticle, their pulp is of sour-sweet taste, green colour, soft consistence, contains approximately 80 fine evenly distributed seeds that are not felt when eating (Paulauskienè et al., 2009). Taste is largely determined by the relative concentrations of acids and sugars present (Marsh et al., 2004). Fruits of all actinidia species are excellent sources of vitamin $\mathrm{C}$. According to previous experiments, the vitamin $\mathrm{C}$ content in the fruit of some hardy kiwifruit such as bower actinidia and kolomikta actinidia is comparable or remarkably higher than in the popular kiwifruit, up to $1164 \mathrm{mg} 100 \mathrm{~g}^{-1}$ of fruit weight for kolomikta actinidia (Ferguson, MacRae, 1992; Nishiyama et al., 2004). In kolomikta actinidia fruits of Lithuanian origin, the amount of vitamin $\mathrm{C}$ in different

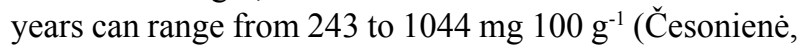
Viškelis, 2007; Paulauskienė et al., 2009). Vitamin C together with total polyphenols is the most important factor of antioxidant activity of actinidia fruits (Park et al., 2006; Krupa, Latocha, 2007; Guorong et al., 2009; Gruzdienè, Kazernavičiūte, 2010). Fruits of actinidia are 
a source of minerals, dietary fibre, various organic acids, vitamin E, carotenoids, flavonoids, and other useful compounds (Nishiyama et al., 2008).

There are a lot of studies done with actinidia fruits for determination of biologically active substances, but almost no data are available on protein and amino acids composition of kolomikta actinidia fruits. The objective of the study was to determine the composition of crude proteins and amino acids in the fruits of Lithuanian kolomikta actinidia cultivars 'Laiba', 'Lankè', 'Landè' and 'Paukštès Šakarva'.

\section{Materials and methods}

The fruits of kolomikta actinidia were obtained from the research orchard of Lithuanian University of Agriculture (currently - Aleksandras Stulginskis University) in 2008-2009. Four cultivars 'Laiba', 'Lankè', 'Landè' and 'Paukštès Šakarva', included in the Lithuanian National List of Plant Varieties since 1997, were used in the investigation. These cultivars were developed by selecting seedlings, grown from free pollination seeds of 'Klara Cetkin' and 'Ananasnaja' cultivars in 1972, and have been under investigation there since 1988 (Pranckietis, Pranckietiene, 2000). Plants of kolomikta actinidia grow in rows; the distance between the plants is $1-1.5 \mathrm{~m}$ and between rows $3 \mathrm{~m}$. Each cultivar grows in a separate row. Fruits were harvested at technical maturity stage. Description of fruits of the investigated cultivars according to breeder Pranckietis et al. (1999) are presented in Table 1.

Table 1. Description of kolomikta actinidia (Actinidia kolomikta) fruits

\begin{tabular}{|c|c|c|c|c|}
\hline & \multicolumn{4}{|c|}{ Cultivar } \\
\hline & 'Laiba' & 'Lankė' & 'Landè' & 'Paukštės Šakarva' \\
\hline Description & $\begin{array}{c}\text { Regular cylindrical shape } \\
\text { with depression in the top } \\
\text { where is remainder of pistil, } \\
\text { calyx pit is shallow }\end{array}$ & $\begin{array}{l}\text { Cylindrical shape, } \\
\text { pointed apex with } \\
\text { remainder of pistil, } \\
\text { calyx pit is shallow }\end{array}$ & $\begin{array}{l}\text { Oblate, } \\
\text { truncated cone shape, } \\
\text { calyx pit is hollow }\end{array}$ & $\begin{array}{c}\text { Cylindrical form, a } \\
\text { bit flattened, pointed } \\
\text { apex with remainder } \\
\text { of pistil }\end{array}$ \\
\hline Average fruit mass $g$ & 2.16 & 2.20 & 3.50 & 4.50 \\
\hline Dry matters \% & $16-19$ & $12-19$ & $12-15$ & $12-19$ \\
\hline Ascorbic acid $\%$ & $0.28-0.92$ & $0.21-0.54$ & $0.25-0.83$ & $0.34-1.00$ \\
\hline Organic acids $\%$ & $0.7-1.3$ & $0.6-1.5$ & $0.5-1.5$ & $0.7-1.8$ \\
\hline Saccharides \% & $5.5-9.8$ & $4.4-8.6$ & $7.0-9.0$ & $3.7-7.4$ \\
\hline
\end{tabular}

Methods of chemical analysis. $100 \mathrm{~g}$ of fruits were sampled from ten plants of each cultivar. Laboratory sample of fruits was a minimum of $1 \mathrm{~kg}$. For analysis fruit pulp was crushed with peel and seeds. For the crude protein analysis $1 \mathrm{~g}$ of the laboratory sample was weighed. The amount of crude protein was determined by Kjeldahl method (ISO 20483:2006). The amount of amino acids was determined in dry matter of fruit. Amino acids were separated by ion exchange chromatography and detected photometrically by measuring light absorbance at 570 $\mathrm{nm}$ with an automatic analyzer of amino acids AAA 339 ("Mikrotechna", Czech Republic), using glass column (Ø $0.37 \times 45 \mathrm{~cm})$, filled with ionite "Ostion LGANB" ("Lachema", Czech Republic). Hydrolysis of the sample was performed in the presence of $6 \mathrm{M} \mathrm{HCl}$ at $105^{\circ} \mathrm{C}$ for 24 $\mathrm{h}$ (Technical regulation..., 2003). Chemical analyses were performed in three replications. The predicted protein efficiency ratio (PER) was calculated using an equation developed by Alsmeyer et al. (1974): P-PER $=-0.468$ +0.454 (Leu) -0.105 (Tyr). The ratio of total essential amino acids (TEAA) to the total amino acids (TAA), amount of total nonessential amino acids (TNEAA), total sulphur amino acids (TSAA), total aromatic amino acids (TArAA), total neutral amino acids (TNAA), total acidic amino acids (TAAA), total basic amino acids (TBAA), branched chain amino acids (BCAA), leucine/ isoleucine (Leu/Ile) ratio and their percentage levels were calculated.

Statistical analysis. The research data were processed by analysis of variance (ANOVA) using computer programme STATISTICA. Arithmetical means and standard errors of the experimental data were calculated. Significant differences among data were evaluated according to Fisher's LSD test. The difference was statistically significant at $p<0.05$.

\section{Results and discussions}

The crude protein content in dry mass of the investigated kolomikta actinidia fruits ranged between $0.96 \%$ and $1.32 \%$. No significant differences among the cultivars were established. The protein content of kolomikta actinidia fruits is similar to that of kiwifruits cv. 'Hayward' (Morton, 1987; Castaldo et al., 1992). In the kolomikta actinidia fruits there were identified 16 amino acids (Table 3). Glutamic acid (7.60-9.51 $\mathrm{g} \mathrm{kg}^{-1}$ ), aspartic acid (4.10-5.01 $\left.\mathrm{g} \mathrm{kg}^{-1}\right)$ and arginine (3.52-4.94 $\mathrm{g} \mathrm{kg}^{-1}$ ) were the most predominant amino acids while methionine $\left(0.42-0.86 \mathrm{~g} \mathrm{~kg}^{-1}\right)$ was the least predominant. Glutamic acid is by far the most important taste enhancing amino acid and aspartic acid contributes also. Glutamic acid is important in the metabolism of sugars and fats. Aspartic acid is of vital importance in the metabolism and construction of other amino acids (Reeds, 2000). The largest amount of glutamic acid was established in 'Laiba' fruits, aspartic acid and arginine in 'Lankè' fruits. Significant differences $(p<0.05)$ were determined among two groups of cultivars - 'Laiba', 'Lankè' and 'Landè', 'Paukštès Šakarva'. Similarly the data of Castaldo et al. (1992) show that arginine and glutamic acid were the major amino acids in Italian kiwi puree. 
All the essential amino acids, except tryptophan, were found in the fruit of all of the investigated kolomikta actinidia cultivars. The predominant essential amino acid in kolomikta actinidia fruits was leucine, whose value ranged from $3.13 \mathrm{~g} \mathrm{~kg}^{-1}$ in 'Lande' fruits to $3.65 \mathrm{~g} \mathrm{~kg}^{-1}$ in 'Laiba' fruits (Table 2). Leucine is the most abundant amino acid in tissue and food proteins but specific demands for non-protein functions have not been identified (FAO/WHO/UNU, 2007).

Table 2. Amount of crude protein and composition of amino acids in kolomikta actinidia (Actinidia kolomikta) fruits ( $\mathrm{g} \mathrm{kg}^{-1}$ of dry mass)

\begin{tabular}{lcccc}
\hline \multicolumn{1}{c}{ Crude protein, } & \multicolumn{3}{c}{ Cultivar } \\
\cline { 2 - 5 } amino acids & 'Laiba' & 'Lanke' & 'Landè' & 'Paukštès Šakarva' \\
\hline Crude protein \% & $1.32 \pm 0.24 \mathrm{a}$ & $1.11 \pm 0.04 \mathrm{a}$ & $0.96 \pm 0.03 \mathrm{a}$ & $1.07 \pm 0.17 \mathrm{a}$ \\
Histidine (His) & $2.02 \pm 0.05 \mathrm{c}$ & $2.00 \pm 0.09 \mathrm{bc}$ & $1.76 \pm 0.02 \mathrm{ab}$ & $1.60 \pm 0.07 \mathrm{a}$ \\
Isoleucine (Ile) & $2.78 \pm 0.05 \mathrm{~b}$ & $2.66 \pm 0.04 \mathrm{ab}$ & $2.48 \pm 0.01 \mathrm{a}$ & $2.44 \pm 0.10 \mathrm{a}$ \\
Leucine (Leu) & $3.65 \pm 0.05 \mathrm{~b}$ & $3.51 \pm 0.10 \mathrm{~b}$ & $3.13 \pm 0.01 \mathrm{a}$ & $3.15 \pm 0.09 \mathrm{a}$ \\
Lysine (Lys) & $1.50 \pm 0.04 \mathrm{~b}$ & $1.39 \pm 0.06 \mathrm{ab}$ & $1.29 \pm 0.03 \mathrm{a}$ & $1.26 \pm 0.06 \mathrm{a}$ \\
Methionine (Met) & $0.86 \pm 0.02 \mathrm{~b}$ & $0.43 \pm 0.01 \mathrm{a}$ & $0.42 \pm 0.01 \mathrm{a}$ & $0.42 \pm 0.01 \mathrm{a}$ \\
Phenylalanine (Phe) & $2.26 \pm 0.02 \mathrm{~b}$ & $2.17 \pm 0.07 \mathrm{~b}$ & $1.91 \pm 0.01 \mathrm{a}$ & $1.96 \pm 0.04 \mathrm{a}$ \\
Threonine (Thr) & $1.96 \pm 0.01 \mathrm{~b}$ & $2.25 \pm 0.02 \mathrm{c}$ & $1.74 \pm 0.01 \mathrm{a}$ & $1.67 \pm 0.03 \mathrm{a}$ \\
Valine (Val) & $2.71 \pm 0.02 \mathrm{c}$ & $2.48 \pm 0.09 \mathrm{~b}$ & $2.28 \pm 0.05 \mathrm{a}$ & $2.24 \pm 0.02 \mathrm{a}$ \\
Alanine (Ala) & $2.65 \pm 0.04 \mathrm{~b}$ & $2.66 \pm 0.12 \mathrm{~b}$ & $2.34 \pm 0.02 \mathrm{a}$ & $2.36 \pm 0.08 \mathrm{a}$ \\
Arginine* (Arg) & $4.28 \pm 0.06 \mathrm{~b}$ & $4.94 \pm 0.02 \mathrm{c}$ & $3.52 \pm 0.01 \mathrm{a}$ & $3.75 \pm 0.19 \mathrm{a}$ \\
Aspartic acid (Asp) & $4.91 \pm 0.15 \mathrm{~b}$ & $5.01 \pm 0.08 \mathrm{~b}$ & $4.26 \pm 0.10 \mathrm{a}$ & $4.10 \pm 0.05 \mathrm{a}$ \\
Glycine* (Gly) & $3.39 \pm 0.03 \mathrm{~b}$ & $3.51 \pm 0.03 \mathrm{~b}$ & $2.88 \pm 0.03 \mathrm{a}$ & $2.88 \pm 0.11 \mathrm{a}$ \\
Glutamic acid (Glu) & $9.51 \pm 0.19 \mathrm{~b}$ & $9.39 \pm 0.00 \mathrm{~b}$ & $7.60 \pm 0.07 \mathrm{a}$ & $8.10 \pm 0.28 \mathrm{a}$ \\
Proline* (Pro) & $2.76 \pm 0.14 \mathrm{ab}$ & $2.93 \pm 0.13 \mathrm{~b}$ & $2.40 \pm 0.03 \mathrm{a}$ & $2.51 \pm 0.06 \mathrm{a}$ \\
Serine* (Ser) & $2.57 \pm 0.05 \mathrm{~b}$ & $3.44 \pm 0.09 \mathrm{c}$ & $2.15 \pm 0.01 \mathrm{a}$ & $2.20 \pm 0.05 \mathrm{a}$ \\
Tyrosine* (Tyr) & $1.45 \pm 0.04 \mathrm{a}$ & $1.38 \pm 0.07 \mathrm{a}$ & $1.29 \pm 0.04 \mathrm{a}$ & $1.27 \pm 0.09 \mathrm{a}$ \\
\hline
\end{tabular}

Notes. ${ }^{*}$ - essential amino acids only in certain cases (Reeds, 2000; Fürst, Stehle, 2004). Significant differences $(p<0.05)$ among the cultivars in row are marked by different letters.

The histidine content in kolomikta actinidia fruits ranged from $1.60 \mathrm{~g} \mathrm{~kg}^{-1}$ in 'Paukštès Šakarva' fruits to $2.02 \mathrm{~g} \mathrm{~kg}^{-1}$ in 'Laiba' friuts (Table 2). In this case significant differences $(p<0.05)$ were determined between 'Laiba' and 'Paukštès Šakarva', also 'Landè' and between 'Lankè' and 'Paukštès Šakarva' cultivars. In the investigated kolomikta actinidia fruits threonine content was higher compared with lysine, and varied from $1.67 \mathrm{~g} \mathrm{~kg}^{-1}$ in 'Paukštès Šakarva' fruits to $2.25 \mathrm{~g} \mathrm{~kg}^{-1}$ in 'Lankè' fruits (Table 2). Methionine, tyrosine and lysine are limiting amino acids in kolomikta actinidia fruits. The amounts of isoleucine, phenylalanine and valine were similar; significantly highest contents of these acids were detected in 'Laiba' fruits $(p<0.05)$, accordingly $2.78,2.26$ and $2.71 \mathrm{~g} \mathrm{~kg}^{-1}$ (Table 2). The highest values of essential amino acids (including histidine) were determined in 'Laiba' and 'Lankè' fruits - 17.71 and $16.87 \mathrm{~g} \mathrm{~kg}^{-1}$, respectively (Fig.). In fruits of 'Landè' and 'Paukštès Šakarva' these values were about $15 \%$ lower 14.99 and $14.72 \mathrm{~g} \mathrm{~kg}^{-1}$, respectively.

The largest amounts of TAA and TEAA were estimated in kolomikta actinidia 'Lanke' fruits (50.11 \pm 0.43 and $33.24 \pm 0.27 \mathrm{~g} \mathrm{~kg}^{-1}$, respectively) (Table 3 ). Fennema (1996) suggests evaluating the biological value of proteins by ratio of TEAA to the TAA (\% TEAA), which should be $31.40-33.90 \%$. In 'Lanke' fruits the recommended ratio of TEAA to the TAA was $33.66 \%$ (Table 3). In fruits of other kolomikta actinidia cultivars the recommended ratio was slightly higher. In fruits of

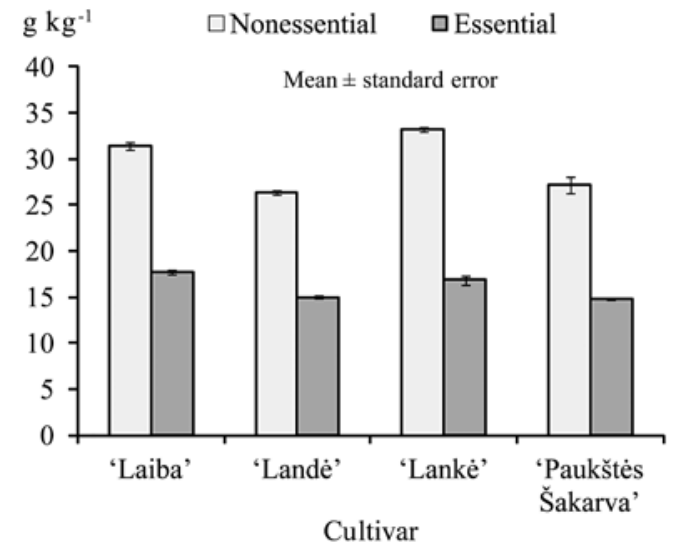

Figure. Essential and nonessential amino acids composition of kolomikta actinidia (Actinidia kolomikta) fruits ( $\mathrm{g} \mathrm{kg}^{-1}$ of dry mass)

kolomikta actinidia the percentage of TEAA was twice as high as in kiwifruits. The percentage of TNAA in kolomikta actinidia fruits was close to the value in kiwifruits. The percentage of TNAA ranged between 53.43-55.51\%, indicating that these formed the bulk of the TAA (Table 3 ). The value of TAAA ranged from 11.86 to $14.41 \mathrm{~g} \mathrm{~kg}^{-1}$, and it was $28.65-29.29 \%$ of TAA (Table 3). These results were highly comparable to the following values of kiwifruits. The value of TBAA was less than half, i.e. $6.57-8.32 \mathrm{~g} \mathrm{~kg}^{-1}$. These results made them the third largest group with $16.76-16.60 \%$ of TAA, while the percentage of TBAA in kiwifruits was twice 
as high (Castaldo et al., 1992). Sulphur amino acids are important metabolically to the extent that their relative requirement for maintenance is probably higher than that for human growth (FAO/WHO/UNU, 2007). The value of TSAA in kolomikta actinidia fruits ranged between $0.08-0.18 \mathrm{~g} \mathrm{~kg}^{-1}$ that equalled $0.86-1.75 \%$ of TAA. This percentage was highly comparable to the following values of kiwifruits (Castaldo et al., 1992).

The amounts of TArAA in fruits of kolomikta actinidia were low - 2.83-3.71 $\mathrm{g} \mathrm{kg}^{-1}$, but bigger than TSAA. The percentage ranged from $5.65 \%$ to $7.71 \%$ and was higher than that of kiwifruits. Phenylalanine and tyrosine are aromatic amino acids. Phenylalanine can be converted in the body to tyrosine, which is the precursor of the catecholamines and thyroid hormone. The requirement for phenylalanine (to meet the needs for phenylalanine plus tyrosine) is an average of $43 \mathrm{mg} \mathrm{kg}^{-1} \mathrm{~d}^{-1}$ and the optimal dietary ratio of phenylalanine to tyrosine is 60:40 (Castaldo et al., 1992; Pencharz et al., 2007). In fruits of kolomikta actinidia the ratio of phenylalanine to tyrosine was close to optimal - 60:38 in 'Lankè', 60:39 in 'Laiba' and 'Paukštès Šakarva', 60:41 in 'Landè' fruits. The BCAA (leucine, isoleucine, valine) are among the nine essential amino acids for humans, accounting for $35 \%$ of the amino acids in muscle proteins and $40 \%$ of the preformed amino acids required by mammals (Shimomura et al., 2004). In kolomikta actinidia fruits the amount of BCAA varied from 7.82 to $9.13 \mathrm{~g} \mathrm{~kg}^{-1}$ and composed $15.73-20.87 \%$ of TAA. This value makes only half of the recommended rate, but is three times higher than in kiwifruits which accumulate only about $6 \%$ (Castaldo et al., 1992). The PER of a food reflects its biological value. Plant proteins, because of their incomplete nature, generally yield to PER values, whereas the values for animal proteins are higher, often above 2.0. The highest PER values of kolomikta actinidia fruits were calculated in 'Laiba' cultivar - 1.04, PER of other fruits did not exceed unit (Table 3).

Table 3. Protein efficiency ratio (PER), amount of essential, nonessential, neutral, acidic, basic, sulphur, aromatic, branched chain amino acids and leucine/isoleucine ratio of kolomikta actinidia (Actinidia kolomikta) fruits ( $\mathrm{g} \mathrm{kg}^{-1}$ of dry mass)

\begin{tabular}{ccccc}
\hline Amino acids groupings & 'Laiba' & 'Lankè' & 'Landè' & 'Paukštės Šakarva' \\
\hline PER & $1.04 \pm 0.02 \mathrm{~b}$ & $0.98 \pm 0.04 \mathrm{~b}$ & $0.82 \pm 0.01 \mathrm{a}$ & $0.83 \pm 0.03 \mathrm{a}$ \\
TAA & $49.20 \pm 0.03 \mathrm{a}$ & $50.11 \pm 0.43 \mathrm{~b}$ & $41.40 \pm 0.29 \mathrm{a}$ & $41.87 \pm 0.15 \mathrm{a}$ \\
TNEAA & $31.49 \pm 0.39 \mathrm{~b}$ & $33.24 \pm 0.27 \mathrm{~b}$ & $26.41 \pm 0.26 \mathrm{a}$ & $27.15 \pm 0.90 \mathrm{a}$ \\
\% TNEAA & 64.00 & 66.33 & 63.79 & 64.84 \\
TEAA & $17.71 \pm 0.25 \mathrm{~b}$ & $16.87 \pm 0.46 \mathrm{~b}$ & $14.99 \pm 0.16 \mathrm{a}$ & $14.72 \pm 0.04 \mathrm{a}$ \\
\% TEAA & 36.00 & 33.67 & 36.21 & 35.16 \\
TNAA & $26.99 \pm 0.17 \mathrm{~b}$ & $27.40 \pm 0.50 \mathrm{~b}$ & $22.98 \pm 0.10 \mathrm{a}$ & $22.37 \pm 0.68 \mathrm{a}$ \\
\% TNAA & 54.86 & 54.68 & 55.51 & 53.43 \\
TAAA & $14.41 \pm 0.33 \mathrm{~b}$ & $14.39 \pm 0.07 \mathrm{~b}$ & $11.86 \pm 0.17 \mathrm{a}$ & $12.20 \pm 0.34 \mathrm{a}$ \\
\% TAAA & 29.29 & 28.72 & 28.65 & 29.14 \\
TBAA & $7.80 \pm 0.15 \mathrm{~b}$ & $8.32 \pm 0.17 \mathrm{~b}$ & $6.57 \pm 0.06 \mathrm{a}$ & $6.60 \pm 0.32 \mathrm{a}$ \\
\% TBAA & 15.85 & 16.60 & 15.94 & 15.76 \\
TSAA & $0.18 \pm 0.02 \mathrm{~b}$ & $0.09 \pm 0.01 \mathrm{a}$ & $0.08 \pm 0.01 \mathrm{a}$ & $0.08 \pm 0.01 \mathrm{a}$ \\
\% TSAA & 1.75 & 0.86 & 1.01 & 1.00 \\
TArAA & $3.71 \pm 0.07 \mathrm{c}$ & $2.83 \pm 0.12 \mathrm{~b}$ & $3.20 \pm 0.03 \mathrm{a}$ & $3.23 \pm 0.12 \mathrm{a}$ \\
\% TArAA & 7.54 & 5.65 & 7.73 & 7.71 \\
BCAA & $9.13 \pm 0.12 \mathrm{~b}$ & $7.88 \pm 0.03 \mathrm{a}$ & $8.64 \pm 0.22 \mathrm{~b}$ & $7.82 \pm 0.20 \mathrm{a}$ \\
\% BCAA & 18.56 & 15.73 & 20.87 & 18.68 \\
Leu/Ile & $1.32 \pm 0.01 \mathrm{ab}$ & $1.32 \pm 0.02 \mathrm{~b}$ & $1.26 \pm 0.00 \mathrm{a}$ & $1.29 \pm 0.02 \mathrm{ab}$ \\
\hline
\end{tabular}

TAA - total amino acids, TNEAA - total nonessential amino acids, TEAA - total essential amino acids, TNAA - total neutral amino acids $(\mathrm{Ile}+\mathrm{Leu}+\mathrm{Met}+\mathrm{Phe}+\mathrm{Thr}+\mathrm{Val}+\mathrm{Ala}+\mathrm{Gly}+\mathrm{Pro}+\mathrm{Ser}+\mathrm{Tyr}), \mathrm{TAAA}-$ total acidic amino acids $($ Asp + Glu $), \mathrm{TBAA}-$ total basic amino acids (His + Lys + Arg), TSAA - total sulphur amino acid (Met), TArAA - total aromatic amino acids (Phe + Tyr), BCAA - branched chain amino acids (Leu + Ile + Val), Leu/Ile - leucine/isoleucine ratio.

Excess leucine in foods interferes with the utilization of isoleucine and lysine. When taken as a major source of protein in the diet, any protein with a Leu/Ile ratio less than 4.6 is considered nutritionally safe. Higher levels of leucine in a diet may induce pellagra, and the leucine/lysine ratio is used as an indicator of the pellagragenic character of a food protein (Mbitki-Mwikya et al., 2000). In all of the investigated kolomikta actinidia fruits Leu/Ile ratio ranged between 1.26-1.32 and it was three and half times less than the recommended rate.

\section{Conclusions}

1. Kolomikta actinidia (Actinidia kolomikta) fruits are not only rich in vitamins and polyphenols but also can be an additional source of amino acids with almost all nonessential and essential (except tryptophan) amino acids. The largest amount of essential amino acids was established in the fruits of kolomikta actinidia 'Laiba' (17.71 $\mathrm{g} \mathrm{kg}^{-1}$ ) and that of nonessential amino acids in 'Lankè' fruits $\left(33.24 \mathrm{~g} \mathrm{~kg}^{-1}\right)$. 
2. The glutamic amino acid is a predominant amino acid in kolomikta actinidia fruits, while methionine, tyrosine and lysine are limiting amino acids. The largest contents of glutamic amino acids were estimated in kolomikta actinidia 'Laiba' fruits $\left(9.51 \mathrm{~g} \mathrm{~kg}^{-1}\right)$.

3. The fruits of kolomikta actinidia 'Lanke' were distinguished by higher amounts of total amino acids, while 'Laiba' exhibited higher contents of total sulphur amino acids and total aromatic amino acids.

Received 20032013

Accepted 05112013

\section{References}

Alsmeyer R. H., Cunningham A. E., Happich M. I. 1974. Equations to predict PER from amino acid analysis. Food Technology, 28: 34-38

Castaldo D., Lo Voi A., Trifiro A., Gherardi S. 1992. Composition of Italian (Actinidia chinensis) puree. Journal of Agricultural and Food Chemistry, 40: 594-598 http://dx.doi.org/10.1021/jf00016a013

Chesoniene L., Daubaras R., Viskelis P. 2004. Biochemical composition of berries of some kolomikta kiwi (Actinidia kolomikta) cultivars and detection of harvest maturity. Acta Horticulturae, 663: 305-308

Česonienė L., Viškelis P. 2007. Evaluation of fruiting potential and berry quality of kolomikta kiwi (Actinidia kolomikta) Sodininkyste ir daržininkystè, 26 (3): 31-39

FAO/WHO/UNU. 2007. Protein and amino acid requirements in human nutrition. Report of a joint $\mathrm{FAO} / \mathrm{WHO} / \mathrm{UNU}$ expert consultation. WHO technical report series, No. 935

Fennema O. R. 1996. Food chemistry ( $3^{\text {th }}$ ed.)

Ferguson A. R., MacRae E. A. 1992. Vitamin C in Actinidia. Acta Horticulturae, 297: 481-488

Fürst P., Stehle P. 2004. What are the essential elements needed for the determination of amino acid requirements in humans? The Journal of Nutrition, 134 (6): 1558S-1565S. $<$ http://jn.nutrition.org/content/134/6/1558S.full.pdf + html $>$ [accessed 1511 2013]

Gruzdienė D., Kazernavičiūtė R. 2010. Aktinidiju riebaliniu ekstraktų antioksidacinis efektyvumas. Chemine technologija, 1 (54): 62-69

Guorong D., Mingjun L., Fengwang M., Dong L. 2009. Antioxidant capacity and the relationship with polyphenol and vitamin C in Actinidia fruits. Food Chemistry, 113 (2): $557-562$ http://dx.doi.org/10.1016/j.foodchem.2008.08.025

ISO 20483:2006. Cereals and pulses. Determination of the nitrogen content and calculation of the crude protein content - Kjeldahl method

Jung K. A., Song T. C., Han D. S., Kim I. H., Kim Y. E., Lee Y. E. 2005. Cardiovascular protective properties of kiwifruit extracts in vitro. Biological and Pharmaceutical Bulletin, 28: 1782-1785 http://dx.doi.org/10.1248/bpb.28.1782

Krupa T., Latocha P. 2007. Antioxidant activity and contents of vitamin $\mathrm{C}$ and phenolic compounds in fruit of various hardy kiwifruit (Actinidia Lindl.) genotypes. Żywność. Nauka. Technologia. Jakość, 5 (54): 239-246 (in Polish)

Marsh K., Attanayake S., Walker S., Gunson A., Boldingh H., MacRae E. 2004. Acidity and taste in kiwifruit. Postharvest Biology and Technology, 32: 159-168 http://dx.doi.org/10.1016/j.postharvbio.2003.11.001

Matich A. J., Young H., Allen J. M., Wang M. Y., Fielder S., McNeilage M. A., Macrae E. A. 2003. Actinidia arguta: volatile compounds in fruit and flowers. Phytochemistry, 63: $285-301$

http://dx.doi.org/10.1016/S0031-9422(03)00142-0
Mbitki-Mwikya S., Ooghe W., Van Camp J., Ngundi D., Huyghebaert A. 2000. Amino acids profiles after sprouting, autoclaving, and lactic acid fermentation of finger millet (Eleusine coracan) and kidney beans (Phaseolus vulgaris L.). Journal of Agricultural and Food Chemistry, 48 (8): 3081-3085 http://dx.doi.org/10.1021/jf0002140

Morton J. 1987. Kiwifruit. Fruits of warm climates, p. 293-300. $<$ http://www.hort.purdue.edu/newcrop/morton/ kiwifruit ars.html> [accessed 0511 2013]

Nishiyama I., Yamashita Y., Yamanaka M., Shimohashi A., Fukuda T., Oota T. 2004. Varietal difference in vitamin C content in the fruit of kiwifruit and other Actinidia species. Journal of Agricultural and Food Chemistry, 52 (17): 5472-5475 http://dx.doi.org/10.1021/jf049398z

Nishiyama I., Fukuda T., Shimohashi A., Oota T. 2008. Sugar and organic acid composition in the fruit of different Actinidia varieties. Food Science and Technology Research, 14 (1): 67-73 http://dx.doi.org/10.3136/fstr.14.67

Park Y. S., Jung S. T., Kang S. G., Drzewiecki J., Namiesnik J., Haruenkit R., Barasch D., Trakhtenberg S., Gorinstein S. 2006. In vitro studies of polyphenols, antioxidants and other dietary indices in kiwifruit (Actinidia deliciosa). International Journal of Food Science and Nutritional, 57: 107-122 http://dx.doi.org/10.1080/09637480600658385

Paulauskienè A., Pranckietis V., Tarasevičienė Ż., Butkutė V. 2009. Productivity of Actinidia kolomikta cultivars and fruits chemical composition. Rural Development: the $4^{\text {th }}$ international scientific conference. Lithuanian University of Agriculture, 4 (1): 372-375

Pencharz P. B., Hsu J. W.-C., Ball R. 2007. Aromatic acid requirements in healthy human subjects. The Journal of Nutrition, 137 (6): 1576S-1578S. <http://jn.nutrition.org/ content/137/6/1576S.full.pdf + html $>$ [accessed accessed 1511 2013]

Pranckietis V., Pranckietienė I., Paulauskienè A. 1999. Actinidia kolomikta - new crop in Lithuania. New Century and Food: scientific practical conference reports. Jelgava, Latvia, p. 54-59

Pranckietis V., Pranckietiene I. 2000. Breeding and crop quality of Actinidia kolomikta in Lithuania. Fruit Production and Fruit Breeding: proceedings of the international conference. Tartu, Estonia, 207: 231-235

Pranckietis V., Paulauskienė A., Jurevičienè V., Tarasevičienė Ž., Pranckietienè I. 2009. Breeding and processing of Lithuanian cultivars of Actinidia kolomikta (Maxim. and Rupr.) Maxim. fruits grown in organic conditions. Zeszyty problemowe postępów nauk rolniczych, 536: 177-183

Reeds P. J. 2000. Dispensable and indispensable amino acids for humans. The Journal of Nutrition, 130 (7): 1835S-1840S. $<$ http://jn.nutrition.org/content/130/7/1835S.full.pdf + html $>$ [accessed 1511 2013]

Scalzo J., Politi A., Pellegrini N., Mezzetti B., Battino M. 2005. Plant genotype affects total antioxidant capacity and phenolic contents in fruit. Nutrition, 21: 207-213 http://dx.doi.org/10.1016/j.nut.2004.03.025

Shimomura Y., Murakami T., Nakai N., Nagasaki M., Harris R. A. 2004. Exercise promotes BCAA catabolism: effects of BCAA supplementation on skeletal muscle during exercise. The American Society for Nutritional Sciences, 134 (6): 1583S-1587S. < http://jn.nutrition.org/content/134/6/1583S. full.pdf + html $>$ [accessed 1511 2013]

Technical regulation of amino acids amount determination in feed. 2003. Normative act compendium. Kaunas, Lithuania, p. 66-77 (in Lithuanian) 
ISSN 1392-3196 / e-ISSN 2335-8947

Zemdirbyste-Agriculture, vol. 101, No. 1 (2014), p. 79-84

DOI 10.13080/z-a.2014.101.011

\title{
Lietuviškos kilmès margalapès aktinidijos (Actinidia kolomikta (Maxim. \& Rupr.) Maxim) vaisių aminorūgščių sudètis
}

\author{
A. Paulauskienė, Ž. Tarasevičienè, A. Žebrauskienè \\ Aleksandro Stulginskio universitetas, Lietuva
}

\section{Santrauka}

Aktinidijų vaisiai yra mineralinių medžiagų, maistinių skaidulų, ịvairių organinių rūgščių, vitaminų $\mathrm{C}$ ir $\mathrm{E}$, karotenoidų, flavonoidų ir kitų žmogaus organizmui naudingų cheminių junginių šaltinis, bet beveik nėra duomenų apie baltymų ir aminorūgščių kiekị juose. Tyrimo tikslas - ištirti žalių baltymų ir aminorūgščių kiekị lietuviškos kilmès margalapès aktinidijos (Actinidia kolomikta (Maxim. \& Rupr.) Maxim) vaisiuose. Tirti keturiu veislių - 'Laiba', 'Lankè', 'Landè', 'Paukštès Šakarva' - vaisiai. Šios veislès buvo išvestos Aleksandro Stulginskio universiteto pomologiniame sode ir tiriamos jau 25 metus. Juose žalių baltymų kiekis nustatytas Kjeldalio metodu, aminorūgštys išskirtos jonų mainų chromatografijos metodu ir nustatytos fotometriškai. Tirtuose margalapių aktinidijų vaisiuose žalių baltymų kiekis kito nuo 0,96 iki 1,32 \%. Esminių skirtumų tarp veislių nebuvo nustatyta. Baltymų kiekis margalapès aktinidijos vaisiuose buvo panašus kaip ir kivio (Actinidia chinensis Planch. (A.Chev) C.F.Liang \& A.R.Ferguson) vaisiuose. Nustatyta, kad margalapès aktinidijos vaisiuose vyraujanti aminorūgštis yra glutamo rūgštis, jos kiekis kito nuo 7,60 iki $9,51 \mathrm{~g} \mathrm{~kg}^{-1}$. Didžiausias nepakeičiamujų aminorūgščių kiekis nustatytas veislès 'Laiba' (17,71 $\left.\mathrm{g} \mathrm{kg}^{-1}\right)$, pakeičiamujų - 'Lankè' $\left(33,24 \mathrm{~g} \mathrm{~kg}^{-1}\right)$ vaisiuose. Visų veislių vaisiuose apskaičiuotas rekomenduojamas nepakeičiamujų aminorūgščių kiekio santykis su bendru aminorūgščių kiekiu, baltymų efektyvumo koeficientas, bendras pakeičiamųjų, turinčių sieros, aromatinių, neutralių, rūgštinių, bazinių ir šakotos grandinès aminorūgščių kiekis, leucino bei izoleucino santykis ir jų procentinis kiekis. Tyrimų rezultatai parodè, kad aminorūgščių kiekis ir jų procentinis kiekis lietuviškų veislių aktinidijų vaisiuose yra panašūs, kaip ir kivių vaisiuose.

Reikšminiai žodžiai: Actinidia, baltymų biologinė vertė, baltymų efektyvumo koeficientas, nepakeičiamosios aminorūgštys, pakeičiamosios aminorūgštys. 